\title{
FANCG wt Allele
}

National Cancer Institute

\section{Source}

National Cancer Institute. FANCG wt Allele. NCI Thesaurus. Code C50987.

Human FANCG wild-type allele is located within 9p13 and is approximately $6 \mathrm{~kb}$ in length. This allele, which encodes fanconi anemia group $\mathrm{G}$ protein, is involved in chromosomal stability and maintenance and DNA interstrand cross-link repair. The allele also plays a putative role in post-replication repair and cell cycle checkpoints. Allelic variants are involved in Fanconi syndrome. 